\title{
Geospatial Application in Mapping Gully Development for Effective Remediation and Control
}

\author{
Charles Udosen ${ }^{1}$, Roberto Olabanjo ${ }^{2} \&$ Abasi-Ifreke S. Etok ${ }^{3}$ \\ ${ }^{1}$ Department of Geography, University of Uyo, Uyo, Nigeria \\ ${ }^{2}$ Nigerpet Structures Ltd, Uyo, Nigeria \\ ${ }^{3}$ Akwa Ibom State, College of Arts and Sciences, Nung Ukim, Ikono, Nigeria \\ Correspondence: Charles Udosen, Snr Lecturer, Fluvial Geomorphologist and GIS pundit, University of Uyo, \\ Nigeria. E-mail: charlesudosen@gmail.com
}

Received: August 22, 2014 Accepted: August 27, 2014 Online Published: November 25, 2014

doi:10.5539/jgg.v6n4p153 URL: http://dx.doi.org/10.5539/jgg.v6n4p153

\begin{abstract}
In south-eastern Nigeria, gully erosion has assumed an alarming proportion and this prompted the use of geospatial information technology to map a gully erosion site in Oron, Akwa Ibom State for effective remediation and control.,. Ground controls were provided in the vicinity of the gully head through the use of dual frequency Leica GPS 1200. The obtained data were downloaded and processed using Leica Geo Office 8.3 and the processed data exported to Arc GIS 10.1 and Auto CAD Civil 3D 2013 for terrain analysis-DEM, Also, the Leica Total Station TS 06 was employed to carry out topographic mapping. The delineated runoff contributing area aided in the computation of maximum discharge (using the Rational method). The computed runoff of $33.919 \mathrm{~m}^{3} / \mathrm{s}$ accounts for the rapid rate gully headscarp retreat at the rate of $1.2 \mathrm{~m} /$ day during the month of July, prior to intervention by the state government. The results obtained were employed in designing gully control structures.
\end{abstract}

Keywords: GIS, DEM, Oron, gully control

\section{Introduction}

Gullies represents extreme manifestation of the complex processes of accelerated soil erosion. It has been an endemic ecological problem of growing concern not only in the humid tropics but in many parts of the world and the literature is replete with numerous studies (Moyensons, 2003; Martinez- Cassanova et al, 2003; Martinez, 2003; Poesen et al, 2003; Valentin et al, 2005; Sirvio et al, 2004; Ronken and Bennett, 2006; Nyssen et al, 2006; Marzolff et al, 2009; Cassali et al, 2009; Poesen, 2011) Many published studies also exist on the mode of occurrence, mapping and assessment and modeling of this phenomenon in an urban environment, particularly in southeastern Nigeria (Udosen, 1998; , 2000; , 2004; , 2006;, 2008, Udosen and Essiett, 2012 ; Akpokodje et al, 2010; Essien and Okon, 2011; Essien and Essen, 2012; Nwilo et al 2011; Ehiorobo et al 2012, ;Ehiorobo and Izinyin 2012; Jonathan and Joshua, 2013; Abdulfatai et al, 2014 amongst others). It is clear from these studies that urban expansion in most parts of Nigeria (as in other countries) leads to increase in impervious surfaces, reduces infiltration rates and consequently increased surface runoff/reduction in concentration time leading to incision and development of gullies. The initiation and growth of gullies, releases large amounts of sediments into receiving streams thereby polluting sources of water supply to the rapidly increasing urban population. This increased sedimentation and water quality problems, which is partly caused by gully erosion and storm water discharge in many drainage basins are the major drivers of urban stream syndrome in Wet Africa (Udosen, 2014) In Oron area of Akwa Ibom State, haphazard arrangements of buildings-unplanned urban development has resulted in severe gully erosion and gullies are ubiquitous geomorphic features on the landscape of the city. The development of gullies in Oron area of Akwa Ibom State, Nigeria has cut off the only access road to the sea port (Figure 1) hence, assessing the interactions between environmental change (land use, climate) and land degradation remains a key issue for environmental scientists, land managers and policy makers in the region. 

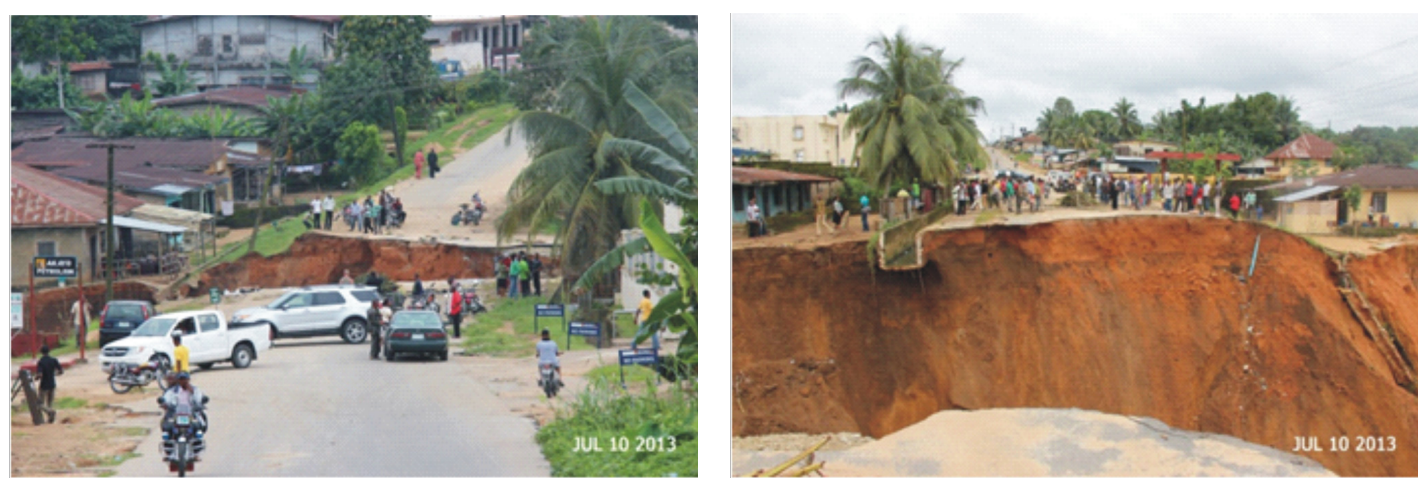

Figure 1. A section of the road destroyed by an impressive gully channel

It is obvious from the available literature on gully erosion that estimating runoff, which is the best predictor of gully erosion remains the most significant contemporary challenges in designing gully control structures. In this regards, the study is aimed at estimating catchment runoff based on detailed field survey and GIS mapping of the gully catchment for appropriate remedial/control measures. The study involves the integration of GPS with total station, remote sensing and GIS-DEM.

Study area Oron is a Local Government Area (LGA) of Nigeria and is located between latitude $4^{\circ} 50^{1} 0^{11}$ North and longitude $8^{\circ} 14^{1} 0^{11}$ East at the right bank of the lower estuary of the Cross River (Figure 2). The people are predominantly fishermen, farmers, and merchants who trade across the Gulf of Guinea frontiers. It is found in the flood plain of South Eastern Nigeria, with the land mainly intersected by numerous streams and tributaries flowing into Cross River. The region is extremely fertile and is known for its Oil Palm from the tropical rainforest. The physiography of this LG A comprises of the Beach ridge complex and the Mangrove swamps From the shoreline with a wide sandy surf beach, to about I0kms inland, is a strip of recently deposited marine sand characterized by a succession of sub parallel sand ridges, which is loose, friable and highly susceptible to erosion once the vegetation is removed. The rainy season begins about March - April and lasts until mid November. Oron receives relatively higher rainfall amounts than other parts of southern Nigeria. The total annual rainfall varies from over $4000 \mathrm{~mm}$ along the coast \{the study area\} to $2000 \mathrm{~mm}$ inland. Heavy rainstorms make up over $80 \%$ of total annual rainfall along the coastal towns.

\section{Methodology}

Rainfall Analysis: Available rainfall data at Oron station, lat. $4^{0} 50^{1} 01^{11} \mathrm{~N}$ and longitude $8^{\circ} 14^{1} 02^{11} \mathrm{E}$ was collected from QIT Meteorological Station). Detailed statistical analysis was carried out to determine the mean total annual, mean monthly, variability in monthly and inter-annual as well as the distribution of rainstorms in the study area. Line and bar graphs were employed to depict temporal variations in rainfall pattern at Oron.

\section{Topographic mapping, GIS and landuse analysis from remotely sensed data}

Orthophoto imagery of the gully site and its environs on a scale of 1:10,000 (Figure 3) was digitized and integrated with the field acquired data to determine housing density. 


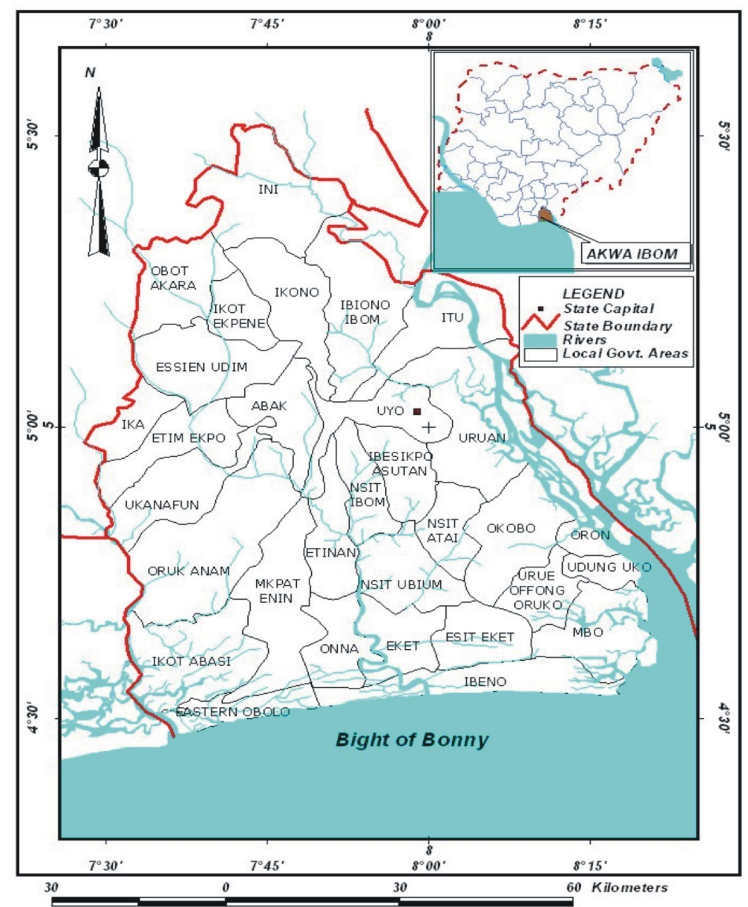

Figure 2. Map of Nigeria \{insert\} showing location of Akwa Ibom State

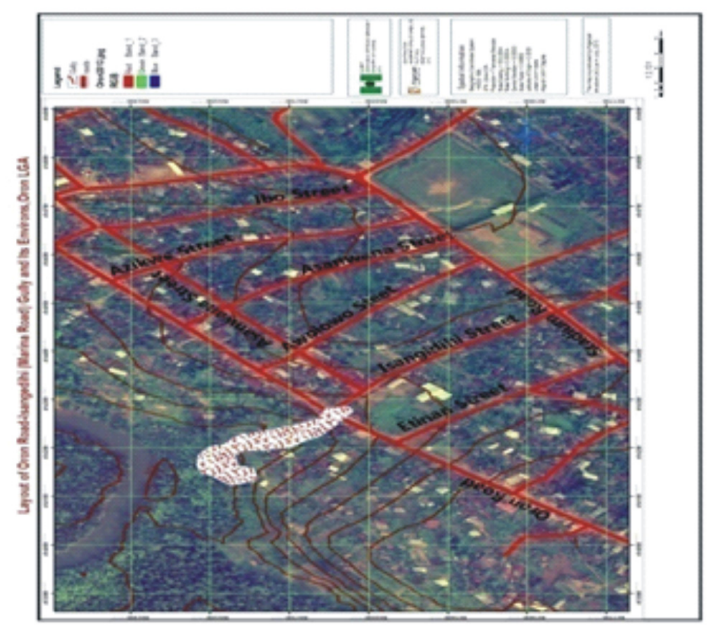

Figure 3. Orthophoto imagery of the study area

Furthermore, topographic map of the area on a scale of 1:25,000 was used to delineate the runoff contributing area. Ground controls were provided in the vicinity of the gully head through the use of dual frequency Leica GPS 1200. The obtained data were downloaded and processed using Leica Geo Office 8.3 and the processed data exported to Arc GIS 10.1 and Auto CAD Civil 3D V2013 for cross sections shown in the appendix. Also, the Leica Total Station TS 06 with all the accessories and supporting equipment were employed to carry out topographic mapping. The acquired data on site was downloaded using Leica construction data manager and processed in Auto CAD Civil 3D 2013 as points (X, Y, Z) for terrain analysis, Triangular irregular Network (TIN) and Digital Elevation Model for 3D visualization.

Calculation of Runoff: The isoline mapping technique was used within the GIS environment to generate contour lines spaces at 1 metre apart to represent the topography of the gully site as well as the profiles of the gully channel. It was then possible to delineate the total sub-catchment area and employ the Rational Method to compute the maximum discharge in the study area. As noted earlier, the contributing area to the gully system is a built up area interspaced with farmlands and a network of paved streets. 


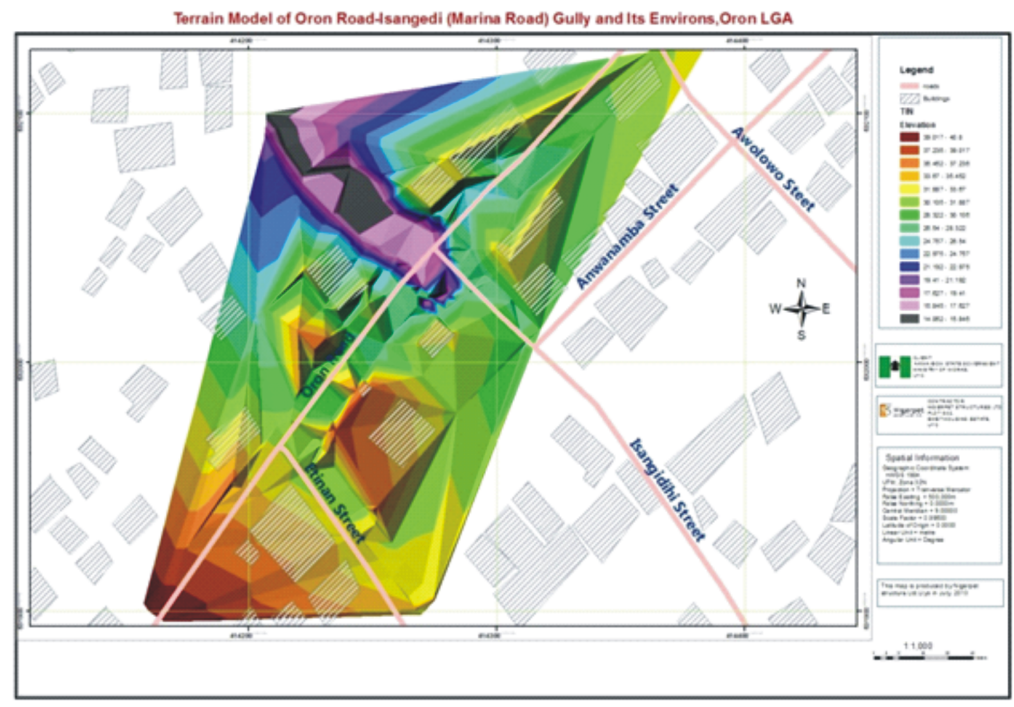

Figure 4. TIN of the sub catchment

A vector based representation TIN (Figure 4) was used instead of the more robust DEM to visualize the configuration of the surface since the catchment is relatively small. The square method was used to compute the gully catchment in $\mathrm{cm}^{2}$ and then multiplied by the scale factor and the gully-catchment expressed in $\mathrm{km}^{2}$. Furthermore, the computed area was converted to hectares by multiplying it with 0.0001 ha The Rational Method was employed in estimating maximum discharge in the area. Rainfall intensity was calculated as $304.65 \mathrm{~mm} / \mathrm{hr}$; length of longest axis was computed from sketch map; the difference in elevation was calculated too, while bare fallow was assumed in the study. The total area was converted to hectares.

The rational formula is expressed as follows;

\section{Run-off Estimates, Q:}

$$
Q=0.278 C I A
$$

$\mathrm{Q}=$ quantity of run-off in cubic meter per second $\left(\mathrm{m}^{3} / \mathrm{s}\right)$

$\mathrm{C}=$ coefficient of run-off expressed as a percentage of imperviousness of the watershed surface $=0.9$

$\mathrm{I}=$ intensity of rate of rainfall expressed in $\mathrm{mm} / \mathrm{hr}$ for a selected frequency and duration equal to certain time of concentration $=304.65 \mathrm{~mm} / \mathrm{hr}$

$\mathrm{A}=$ area of the watershed $($ Catchment $)=0.445 \mathrm{~km}^{2}$

The maximum discharge was estimated by first computing the time of concentration of runoff. Time of concentration Tc is defined as the time required for water to flow from the most remote[in time of flow] point of the area to the outlet once the soil has become saturated and minor depressions filled. Using the Kirpich equation (1940) is given by; (2)

Where

$$
\mathrm{Tc}=0.0195 \mathrm{~L}^{0.77} \mathrm{~S}^{-0.385}
$$

$\mathrm{Tc}=$ time of concentration of runoff

$\mathrm{L}=$ maximum length

$\mathrm{S}=$ Slope

Global water flow probe was used to determine the water velocity and depth of discharge in road side drain that runs into the gully. The recorded velocity was $2.4 \mathrm{~cm} / \mathrm{s}$.

\section{Results and Discussions}

\subsection{Rainfall Analysis}

The pattern of monthly rainfall depicts a unimodal shape with very high rainfall in the months of June to September and some years do not show the little dry season in August, known locally as August break (Udosen, 
2008b). It is quite evident that the duration of rainy season ranges from eleven to eight months (Figure 5) based on the periods of records i.e. 1995 to 2002.

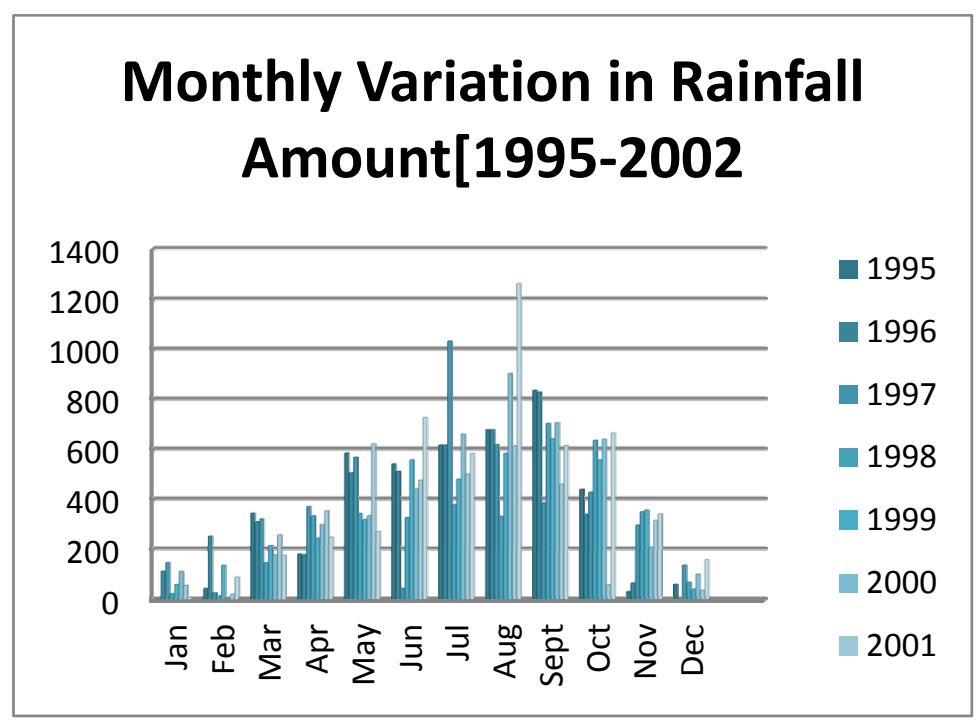

Figure 5. Monthly rainfall at Oron (1995-2002)

The available records of total annual rainfall in the coastal town of Akwa Ibom State, as recorded in Oron shows that it ranges from $3668.2 \mathrm{~mm}$ observed in 1998 to $5286.6 \mathrm{~mm}$ recorded in the previous year, 1997. On the average the total annual rainfall expected is over $4000 \mathrm{~mm}$, compared to about $2540 \mathrm{~mm}$ at Uyo, the state capital located north of the study area (Udosen, 2008b). In a sharp contrast, the inter-annual variability of rainfall recorded between 1992 and 2008 shows slight departure from the mean value as shown in Figure 6. It clearly indicates high degree of reliability of rainfall during the rainy season, unlike the continental towns such as Uyo.

Table 1. Rainfall at Oron (1992-2008)

\begin{tabular}{lll}
\hline YEAR & TOTAL ANNUAL & MAXIMUM MONTHLY \\
\hline 1992 & 4351.1 & 885.3 in August \\
1993 & 3799.0 & 719.7 in August \\
1994 & 4939.0 & 1098 in July \\
1995 & 4367.0 & 836.6 in September \\
1996 & 4574.0 & 836.6 in September \\
1997 & 5286.4 & 1033.8 in July \\
1998 & 3668.3 & 704.7 in September \\
1999 & 4206.2 & 642.7 in September \\
2000 & 4597.5 & 904.8 in August \\
2001 & 3782.8 & 623 in May \\
2002 & 5159.0 & 1262.8 in August \\
2003 & 4757.8 & - \\
2004 & 4356.7 & 752.7 in June \\
2005 & 4679.4 & 865.6 in June \\
2006 & 4717.9 & 866.0 in September \\
2007 & 4556.9 & 816.2 in September \\
2008 & 4562.1 & 972.1 in July \\
Mean value & $4318.4 \mathrm{~mm}$ & \\
\hline
\end{tabular}

Source: NDDC (2011) and QIT Meteorological station, Mobil Unltd.

Analysis of frequency of occurrence of maximum monthly rainfall indicates that the month of August has the highest frequency of $37.5 \%$ followed in descending order by September (25\%), July (18.75\%), June (12.5\%) and 
finally May (6.25\%), Table 2 and (Figure 7). The implication is that the gully at Oron, which has already advanced across the road will continue to expand at an alarming rate before the end of the wet season in 2013, if nothing is done and would have devoured the building of Access Bank and a Petrol filling station, presently under constant threat.

Table 2. Frequency of maximum monthly rainfall along the Coast

\begin{tabular}{lll}
\hline MONTH & FREQUENCY & PERCENTAGE \\
\hline May & 1 & 6.25 \\
June & 2 & 12.5 \\
July & 3 & 18.75 \\
August & 6 & 37.5 \\
September & 4 & 25 \\
\hline
\end{tabular}

Source: Rainfall Data at Oront1992-2008).

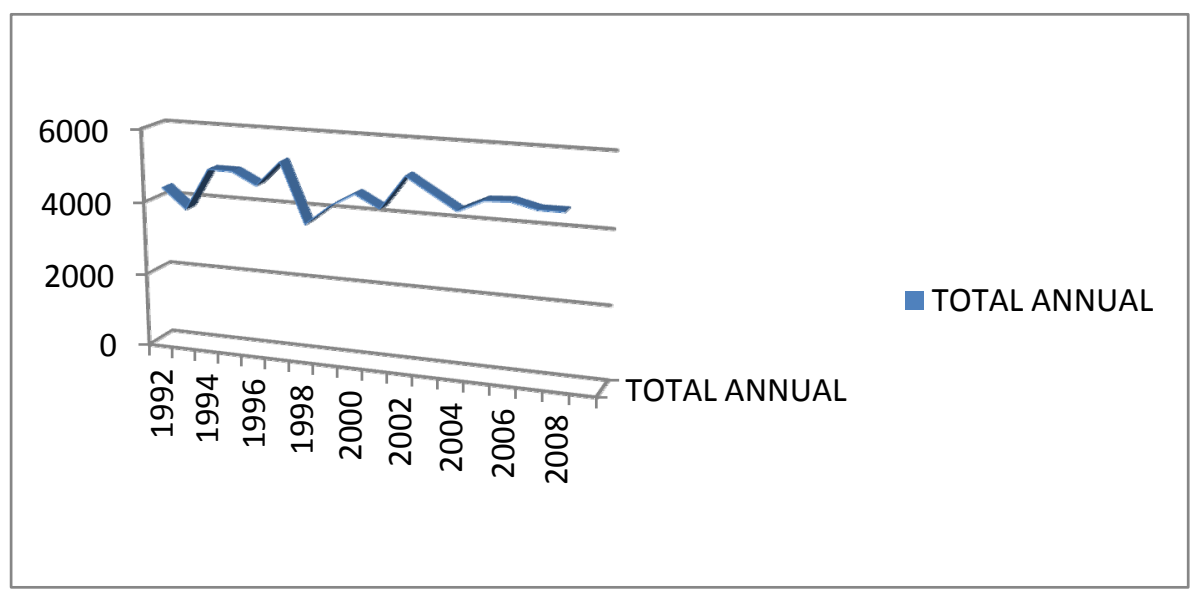

Figure 6. Inter-annual variability of total rainfall from 1992 to 2008

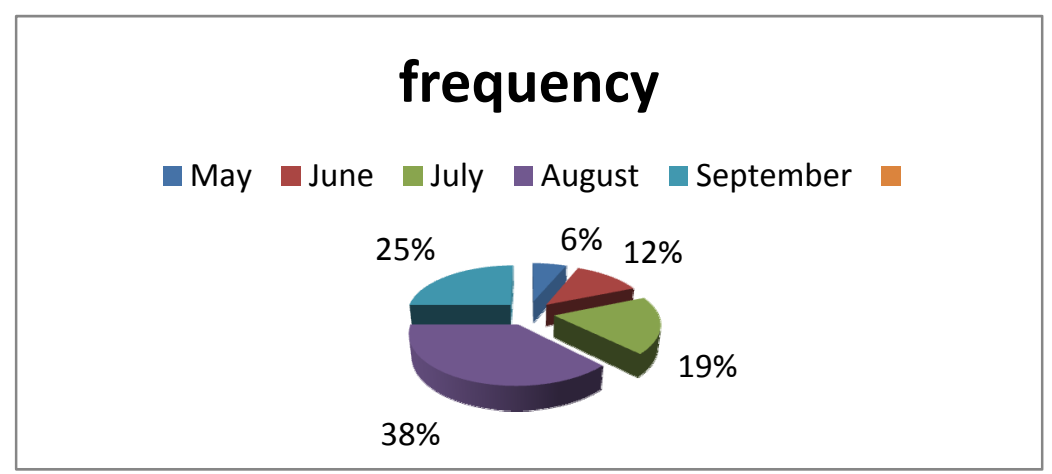

Figure 7. Frequency of occurrence of maximum monthly rainfall

Apart from mean total annual rainfall, its inter annual variability and monthly distribution, engineers and hydrologists require information on the distribution of rainstorms, probable maximum rainfall and the relationship between intensity, duration, and frequency of rainstorms[IDF] for the design of storm drains, culverts, and gully erosion control. The design of such structures must be based on the magnitude of flows which the structures will likely have to withstand during its estimated economic life considering that gully erosion is caused by intense and/or prolonged rainfall. Table 1 of the appendix indicates that severe gully erosion is intensified in the months of April to October. 


\subsection{Computation of Runoff}

Gully erosion has continued to wreak havoc in Oron LGA of Akwa Ibom State, as ravaging awe-inspiring chasm has tore the city into two. The gully system is located within the built up area, where the building density is up to 40 / ha. Gullies in the area became pronounced since 2011 while the rapid advancement towards the buildings (Figure 8) became obvious since the onset of 2013 wet season. The mostly trapezoidal shaped gully channel (Figure 9) which was initiated barely eighteen years ago has assumed an endemic proportion. It is more than $124 \mathrm{~m}$ long, highly variable in shoulder width ranging from $8 \mathrm{~m}$ to $20 \mathrm{~m}$, while the bedwidth varies from $2 \mathrm{~m}$ to $>13 \mathrm{~m}$ with an average depth of $8.3 \mathrm{~m}$ ( (cf Figure 8 ).
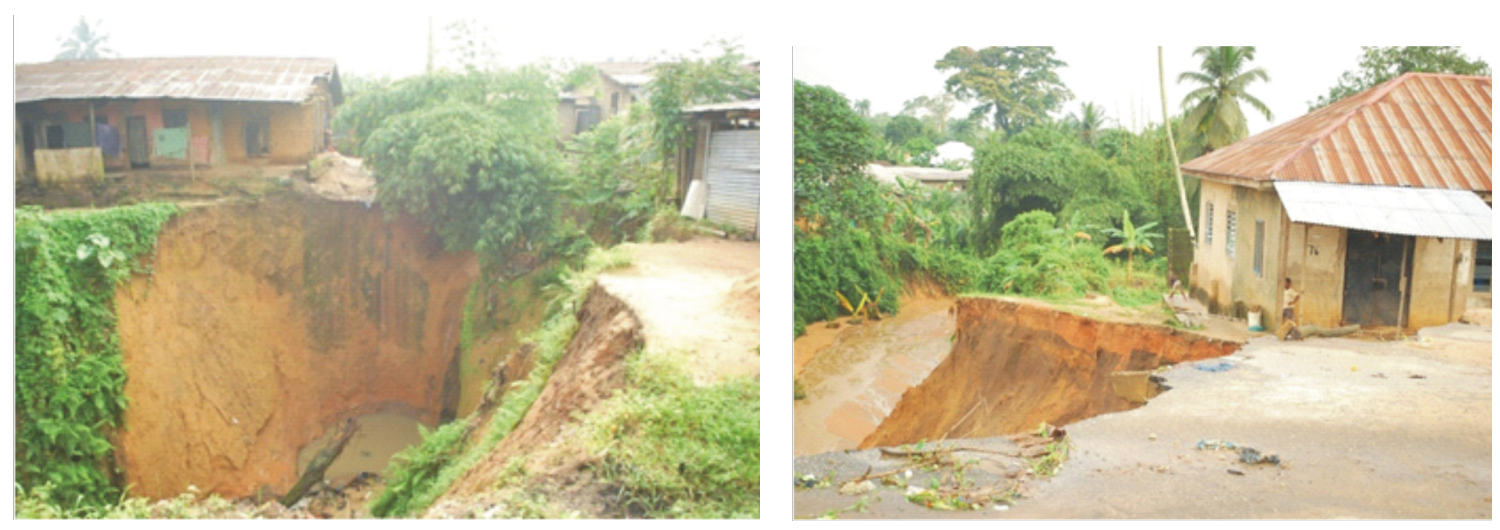

Figure 8 . These buildings have been abandoned by the residents
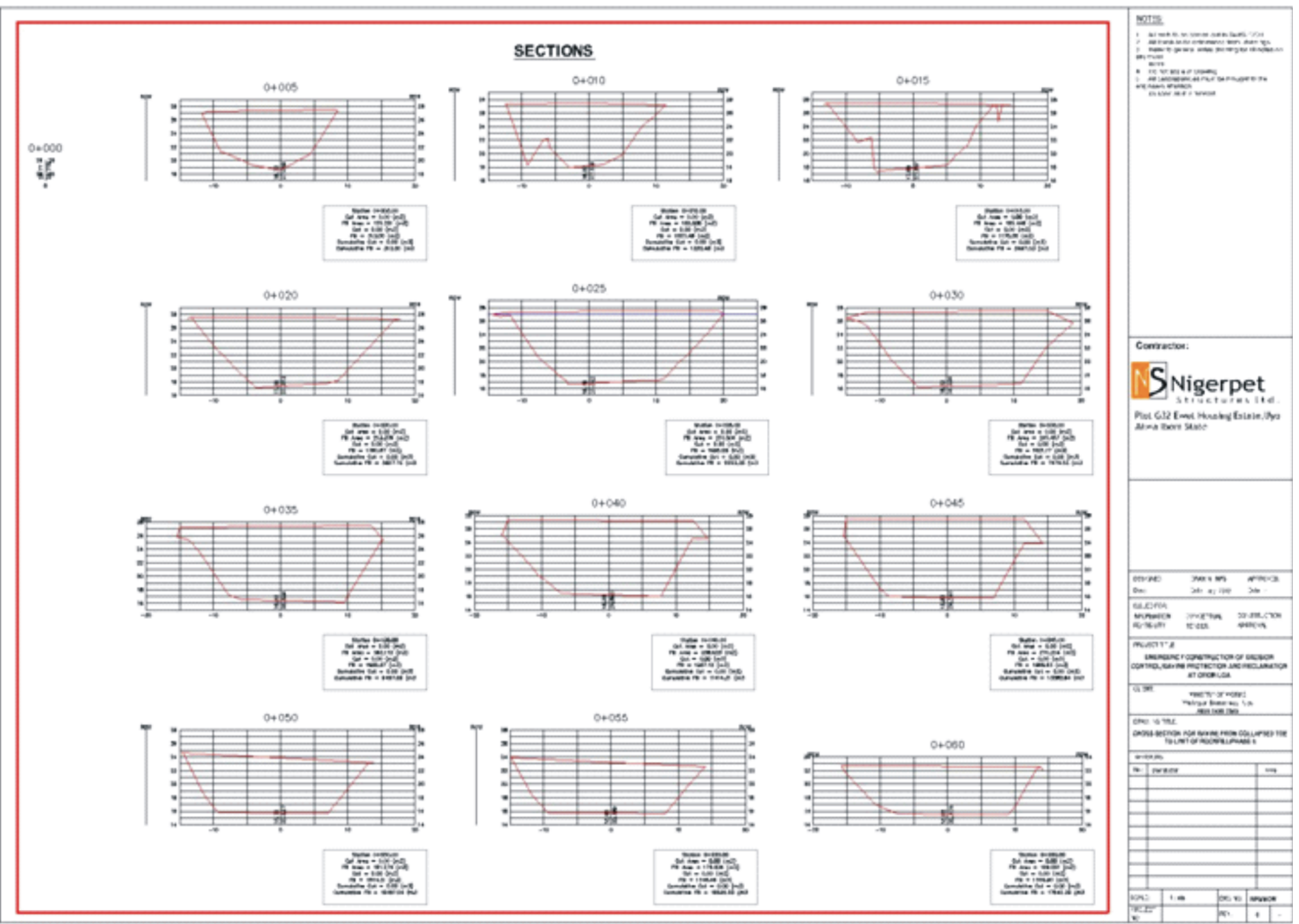

Figure 9. Cross sections of the gully channel 
The base level of erosion relative to Etim Inyang River is $40 \mathrm{~m}$ and most of the adjoining streets i.e Etienam, Awolowo, Isangedighi, and Amwanaba contribute with enormous volume of runoff to the gully channel (cf Figs 3 and 4.). For instance, our field observation on the discharge drain adjacent to Access Bank with dimension $1.2 \mathrm{~m}$ by $1.2 \mathrm{~m}$ gave a reading through the use of Flow meter, -of $1.2 \mathrm{~m} / \mathrm{s}$ two hours after rainfall and this particular drain overflowed during most of the rainstorms. Gullies in the area became pronounced since 2011 while the rapid advancement towards the buildings became obvious since the onset of the wet season in 2013. All the streets/roads studied were also poorly provided with drainage systems. Therefore significant proportion of the surface runoff flows along the untarred roads and the unpaved drains. In some areas, where concrete drains and culverts are constructed, runoff drains directly into the gully head, as shown in orthophoto imagery of the gully site (cf Figure 3). Fig 4 shows that the catchment area is almost circular, with a very short concentration time of 7 minutes. Another interesting feature is that virtually all the adjoining streets contribute with surface runoff to the gully head at the same time, thereby reducing the time of concentration of surface runoff. Often during rainstorms the process of basal undercutting at the gully headscarp is enhanced and subsequently the gully side collapses and the debris at the gully floor is swept by ephemeral flow of water on gully floor. Similarly, the computed maximum discharge of $33.919 \mathrm{~m}^{3} / \mathrm{s}$ explains the spasmodic nature of gully headscarp retreat at the rate of $1.2 \mathrm{~m} /$ day during the month of July, prior to intervention by the state government. It then means that a rainfall event that lasts for an hour will generate a maximum discharge of $33.919 \times 3600 \mathrm{~m}^{3} / \mathrm{s}$ into the deep gully system. It is true that without the intervention, the entire residential buildings including a bank and a petrol filling station would have caved in between July and September 2013, bearing in mind the severity of rainfall in these months. Presently, about ten buildings including a church are at the edge of another gully system radiating from Etim Inyang River on the same Oron road at Awolowo/Oron road junction.

Detailed base map analysis shows that the gully complex is intricately linked to the major drainage systems i.e Etim Inyang River, which is laden with sediments sourced mainly from the nine metres deep gully channel. According to a resident in the area, the owner of the building that collapsed following heavy downpour in Oron, lost everything, The victim, whose house built 16 years ago collapsed into the ravine, blamed the disaster on gully erosion that went unchecked. Furthermore, he claimed that when he moved to the area, there was no gully, adding that what later developed to become a gully occurred less than two years ago. He explained that the little crack on the ground, which they tried to check using sandbags, later grew to become the awe-inspiring chasm.

At the time of the study, about 25 of houses cling precariously to the edge of the gully system. Observations showed that some buildings in the gully affected area have been abandoned, and many of those still occupied were at the verge of collapsing into the channels. Most severe damage to properties was observed in gully headscarp which is broadly-loped.

Another salient reason why Oron is prone to gully erosion is due to the weak, unconsolidated and porous coarse-textured sandy soils formed from the Coastal Plains Sands. These soils are unstable to raindrop impact and slake on quick wetting. The catchment lithology is primarily Coastal Plain Sands with loamy sand to sandy surface materials. Granulometrical composition of soils are; coarse Sand, $55-86 \%$, Clay, 2-15\%, Silt, 0-17\%. The infiltration rate ranges from $5 \mathrm{~mm} / \mathrm{hr}, 19 \mathrm{~mm} / \mathrm{hr}$ to $111.3 \mathrm{~mm} / \mathrm{hr}$ for bare, scanty vegetation and forest cover respectively (Udosen, 2008a). The increasing rate of destruction of natural vegetation in the course of farming, through unwise clearing and burning of vegetation and indiscriminate farming on slopes also complicate issues of soil degradation.
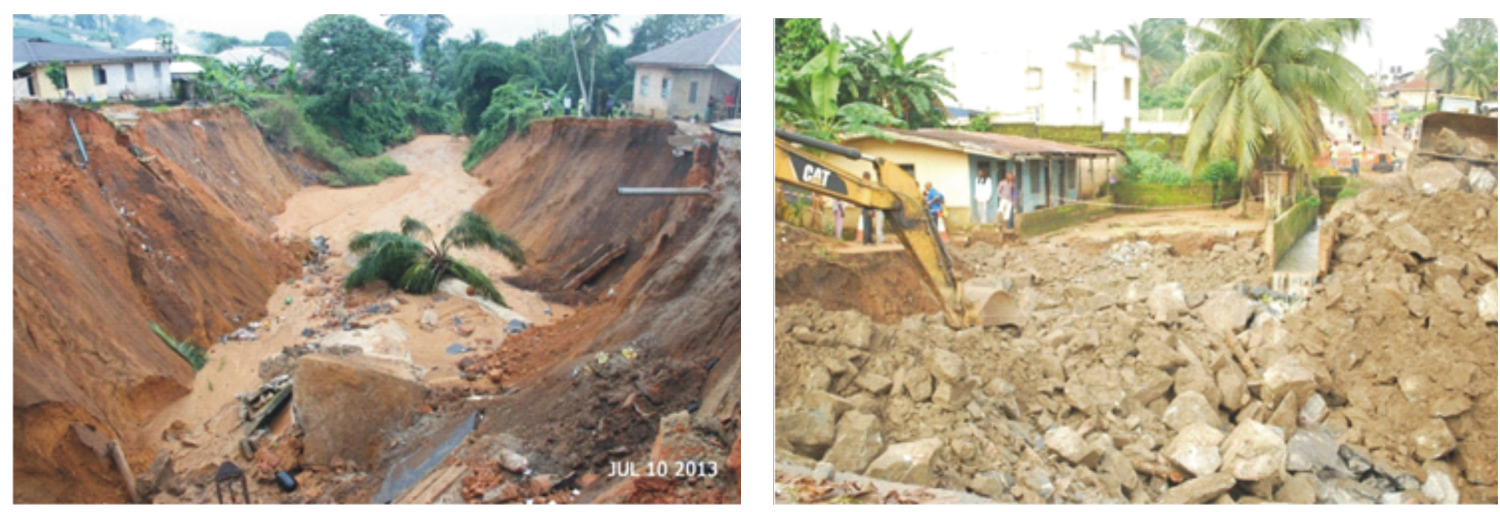

Figure 10. Rock filling to re-grade the wide gully channel 
In conclusion, the gully complex at Oron is caused by heavy rainfall exceeding the capacity of the drainage systems which include the outfall drains, the culverts, the outfall structures, and the estimated catchment area; Increased paved area giving rise to increased run-off; other anthropogenic activities in the vicinity of the gully; the weak and unconsolidated coarse-textured coastal plains sand. This soil type is prone to erosion as it is unstable to raindrop impact and slides easily while wet. The application of geospatial technology and the computation of the maximum discharge facilitated the design of gully stabilization structures (appendix 2). These erosion control structures consist of an efficient outfall drainage systems which will improve underground and surface drainage, re-grading the gully through rock filling (Figure 10) and construction of stabilized runoff channel and slope stabilization.

\section{Acknowledgements}

Nigerpet Structures Nigeria Limited is acknowledged for appointing the corresponding author- Dr C.E Udosen as a consultant Hydrologist in erosion/flood control projects.

\section{References}

Abdulfatai, I. A., Okunrola, I. A., Akande, N. G., Momoh, L. O., \& Ibrahim, K. O. (2014). Review of Gully erosion in Nigeria, Causes, Impacts and Possible Solutions. Journal of Geosciences and Geomatics, 125-12.

Akpokodje, E. G., Tse, A. C., \& Ekeocha, N. (2010). Gully Erosion Geohazards in South eastern Nigeria and Management Implications, Scientia Africasia 9 91) 20-36.

Assefa, D., Zegeye, T., Tebebu, Y., Anteneh, Z. A., Helen, E. D., Eric, D. W., ... Tamnos, S. S. (2010). Assessment of Hydrological and landscape controls on gully formation and upland erosion near Lake Tana' CP Project Workshop Proceedings, pp. 162-169.

Casali, J. Gimenez, R., \& Bennett, S. (2009). Gully erosion Processes and modeling. Proc. Fourth Int. Sympossium on Gully Erosion, Pamplona, Spain, Sept. 2007. Earth Surface Processes and Landforms, 34, 1839-1984.

Ehiorobo, J. O., \& Audu, H. A. P. (2012). Monitoring of Gully Erosion in an Urban Area Using Geoinformation Technology. Journal of Emerging Trends in Engineering and Applied Sciences [JETEAS], 3(2), 270-275.

Ehiorobo, J. O., \& Izinyon, O. C. (2012). 'Monitoring Gully Formation and Development for Effective Remediation and Control' FIG Working week 2012 knowing to manage the territory, protect the environment, evaluate the cultural heritage, Rome, Italy, 6-10 May, 2012.

Essien, O. E., \& Essen, I. A. (2012). Gully Growth Pattern and soil Loss under Rainfall at Urban Underground Drainage Construction Site, Uyo' Research Journal of Applied Sciences. Engineering and Technology, 4(16), 2616-2625.

Essien, O. E., \& Okon, E. G. (2011). Rainfall Characteristics, runoff rate and traffic flow on gully morphometric parameter growth and soil loss in sand-mined peri-urban, Uyo. Nigeria' Journal of Geology and Mining Research, 3(7), 180-187.

Jonathan, O., \& Joshua, B. (2013). Geospatial Application in Mapping Gully Erosion Sites in Jos Plateau State, Nigeria. Scholarly Journal of Scientific Research and Essay (SJSRE), 2(6), 85-95.

Martinez- Cassanova, J. A., Ramos, M. C., \& Poesen, J. (2003). Assessment of sidewall erosion I large gullies using multi-temporal DEMs and logistic regression analysis. Geomorphology, 58(1-4), 305-321.

Martinez-Cassanova, J. A. (2003). A Spatial Information Technology approach for the mapping and quantification of gully erosion. Catena 50(2-4), 293-300.

Marzolff, I., \& Poesen, J. (2009). The Potential of 3D Gully monitoring with GIS using high- resolution aerial Photography and a digital photogrammetry system. Geomorphology, 111, 4-60. http://dx.doi.org/10.1016/j.geomorph.2008.05.047

Moyersons, J. (2003). The topographic thresholds of hillslope incisions I south western Rwanda. Catena, 50(2-4), $381-400$.

NDDC (2011). EIA of Construction and Upgrade of 17km Eket-Ibeno-QIT Road, Akwa Ibom State.

Nwilo, P. C., Olayinka, D. N., Uwadiegwu, I., \& Adzandehi, A. E. (2011). An Assessment and Mapping of Gully Erosion Hazards in Abia State. A GIS Approach Journal of Sustainable Development, 4(5).

Nyssen, J., Poesen, J., Veeyret-Picot, M., Moeyersons, J., Haile, M., Deckers, J., ... Govers, G. (2006). Assessment of gully erosion rates through interviews and measurements: A case study from northern 
Ethiopia. Earth Surface Processes and Landforms, 30, 167-185.

Poesen, J. (2011). Challenges in Gully Erosion Research. Landform Analysis, 16, 5-9.

Poesen, J., Nachterhaile, J., Verstraeten, G., \& Valentin, C. (2003). Gully erosion and environmental change : importance and research needs. Catena, 50(2-4), 91-133.

Romkens, M. J. M., \& Bennett, S. J. (2005). Gully Erosion. Proc. Third Int. Sympossium on Gully Erosion, Oxford, MS, USA, April 2004. Int. JOUR. Of Sediment Research, 20(3), 157-280.

Sirvio, T. A., Rebeiro, H., \& Pelikka, P. (2004). Geoinformation in gully erosion studies in Taita Hills, SE-Kenja, Preliminary Results. In the Proceedings of the Assiciation of Remote Sensing of the Environment Conference, 17-22 Oct. 2004.

Udosen, C. E. (1998). Accelerated Erosion in a Rapidly Urbanizing Watershed in Uyo Area Akwa Ibom State. In I. E. Ukpong (Ed.), Geography and the Nigerian Environment (Afanide \& Bros Publishing Co. Uyo pp. 230-238).

Udosen, C. E. (2000). Thresholds of Gully Erosion in the Coastal Plains Sands of Eastern Nigeria: A Case Study of Ikpa River Basin. Unpublished Ph.D. Dissertation, Department of Geography, University of Ibadan, Oct., 2000.

Udosen, C. E. (2004). A Multivariate Approach for Predicting Gully Initiation and Development in South Eastern Nigeria. Nigerian Journal of Agriculture, Food \& Environment, 1(1), 40-47. Faculty of Agriculture, University of Uyo.

Udosen, C. E. (2006). Relief, Land Use and Erosion Risk in Ikpa River Basin. Nigerian Journal of Agriculture, Food and Environment, 2(2), 51-57. Faculty of Agriculture, University of Uyo.

Udosen, C. E. (2008a). Gully Erosion in Ikpa River Basin: A threshold phenomenon. Published by Time Communications. Lagos, Nigeria. p295.

Udosen, C. E. (2008b). Rainfall analysis and forecasting in Akwa Ibom State. Published by Unwana Press, Uyo, Nigeria.

Udosen, C. E. (2012). Digital Elevation Model as a tool for Monitoring and Evaluating gully Development in a Humid Tropical Environment. Online Journal of Earth Sciences, 6(2-6), 6-14.

Udosen, C. E. (2014). The impact of land-use and human perturbation on urban stream water quality in the humid tropical environment' Presented at Third Sympossium on Urbanization and Stream Ecology SUSE3 - Crowne Plaza Portland-Downtown Convention Centre Hotel, Portland, Oregon (USA), May 15-17, 2014.

Valentin, C., Poesen, J., \& Li, Y. (2005). Gully Erosion: A Global Issue. Proc. Seond Int. Sympossium on Gully Erosion, Chengdu, China, May 2002. Catena, 6 (2-3), 129-330.

\section{Appendix 1}

Monthly Rainfall at Oron Recorded Between 1995 and 2002

\begin{tabular}{lllllllll}
\hline MONTH & 1995 & 1996 & 1997 & 1998 & 1999 & 2000 & 2001 & 2002 \\
\hline Jan & 0.2 & 112.3 & 146.0 & 23.1 & 59.7 & 111.7 & 56.2 & 10.9 \\
Feb & 43.9 & 253.9 & 26.3 & 14.8 & 135.5 & 1.8 & 20.8 & 88.8 \\
Mar & 346.2 & 311.7 & 323.1 & 145.3 & 215.5 & 176.7 & 259.2 & 175.2 \\
Apr & 180.2 & 177.8 & 372.6 & 335.5 & 245.9 & 300.6 & 355.3 & 249.9 \\
May & 587.0 & 507.5 & 570.3 & 345.4 & 320.7 & 336.2 & 623.0 & 272.5 \\
Jun & 543.1 & 513.1 & 043.5 & 328.6 & 559.4 & 443.9 & 477.3 & 728.8 \\
Jul & 617.9 & 617.9 & 1033.8 & 380.4 & 482.0 & 661.9 & 502.7 & 585.8 \\
Aug & 679.6 & 679.6 & 619.0 & 333.2 & 586.2 & 904.8 & 614.3 & 1262.8 \\
Sept & 836.6 & 830.2 & 387.7 & 704.7 & 642.7 & 707.9 & 461.1 & 615.9 \\
Oct & 440.8 & 342.1 & 429.7 & 636.9 & 559.1 & 641.3 & 58.4 & 666.5 \\
Nov & 31.4 & 65.3 & 298.2 & 351.6 & 358.5 & 210.4 & 317.2 & 343.5 \\
Dec & 60.1 & 9.2 & 136.2 & 68.8 & 41.0 & 100.3 & 37.1 & 158.4 \\
\hline
\end{tabular}

Source: Analyzed from data recorded at QIT Meteorological station. 


\section{Appendix 2}

\section{Gully erosion control Structures}

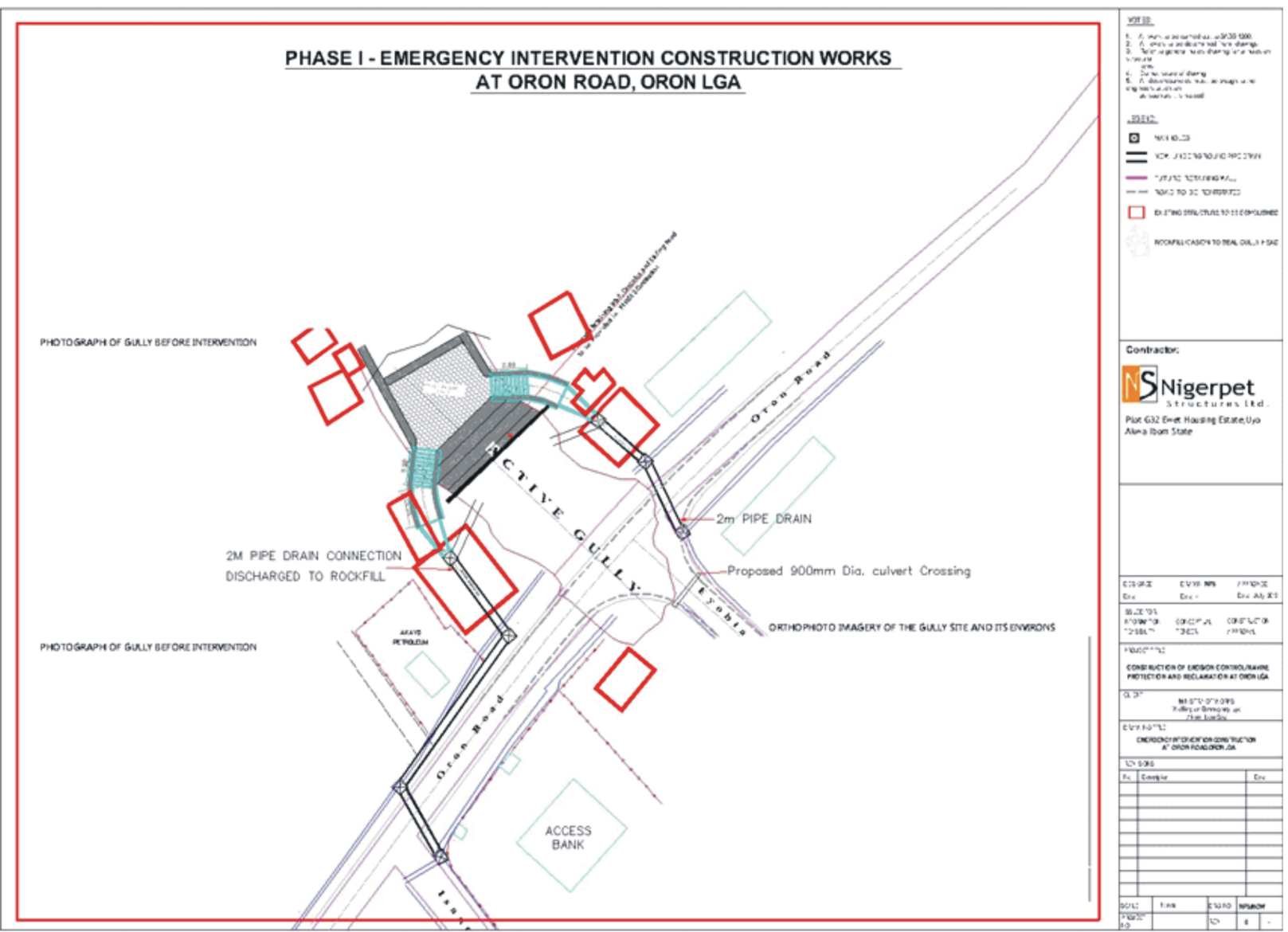

